\title{
A Comparative Study Between Grape (Vitis vinifera) Juice Varieties on Liver Toxicity Induced by Sodium Fluoride in Adult Rats
}

\author{
Naglaa A. EL-Sheikh, Abeer A. Khedr and Alaa H. Nofal
}

Department of Nutrition and Food Sciences, Faculty of Home Economics, Menoufia University, Shibin El- Kom, Egypt

\section{ABSTRACT}

The consumption of fruits has an important role in health protection.
Grape juice is considered a healthy protecting beverage due to its high
content of bioactive phenolic compounds and their antioxidant capacity.

The present study was designed to compare the potential effects of three types of grape juice (Green or white-red and black) against the toxicity and tissues damage induced by sodium fluoride $(\mathrm{NaF})$ in rats liver. Rats were randomly divided into five groups. The first: negative control group (6 rats) fed standard diet. From 2 to 5 group received a single oral dose $10.3 \mathrm{mg} \mathrm{Naf} / \mathrm{kg}$ body weight for six weeks, the second group served as positive control group (6 rats), the third, fourth and fifth groups (12 rat leach) were fed standard diet and each of them was divided into two sub groups (6 rats /each) and given a daily oral dose 5 and $10 \mu \mathrm{L} / \mathrm{g}$ body weight for 6 weeks of the green (white), red and black grape juice respectively. After the end of the experimental period, lipids profile, liver functions, Malonaldehyde (MDA) levels, reduced glutathione (GSH Rd) and catalase (CAT) activities and histological examination of liver tissues were performed. Results showed that NaF treated rats caused elevation in lipid profile, liver functions in the serum and MDA levels with reduction in the activity of GSH Rd and CAT in liver tissues. However, treatment sodium fluoride rats with red and black grape juice reduced the levels of lipid profile, liver enzymes and MDA with enhanced activity of GSH Rd, CAT and histopathological changes in the liver tissues. While, treated rats with black grape juice $(10 \mu \mathrm{l} / \mathrm{g} B W)$ was more effective in alleviating the harmful effects of $N a F$ in rats. In conclusion, red and black grape juice has a potent effect against $\mathrm{NaF}$ induced hepatotoxicity in rats and this effect might be correlated with grape antioxidant capacity.

Key words: liver toxicity, sodium fluoride, red and black grape juice, liver functions,. 
Naglaa A. EL-Sheikh, Abeer A. Khed and Alaa H. Nofal

\section{INTRODUCTION}

Fluorinated compounds such as sodium fluoride, sodium fluorosilicate and cryalite (a fluoride - containing mineral) are used in various insecticide formulations and wood preservatives (Nabavi et al., 2012). Fluoride, an essential trace element is widely distributed in nature as its compounds or free ions. Fluorosis in human beings is mainly caused by drinking water, toothpaste, mouth rinses, burning cool, NaF dust and fumes from industries using NaF- canting salt and hydrofluoric acid, and drinking tea (Liu et al., 2003). Fluoride easily distributes in the body through blood circulation, crosses the cellular membrane and its subsequent accumulation leads to impairment in the soft tissues (Bouaziz et al., 2010). Excessive intake of fluoride causes adverse health effects such as fluorosis in mammals and other toxic effects on cultured tissues (He and Chen, 2006 and GAO et al., 2009b). Also the excessive exposure to fluoride can lead to some toxicological risks as fluoride intoxication is associated with severe damage to different tissues (Nabavi et al., 2012 ab).

Chronic fluorosis may induce hyperlipidemic effect (Khudiar and Aldabaj, 2014) metabolic, functional and structural damages in many tissues including kidney (Nabavi et al., 2013) and liver (Grucka - Mamczar et al., 2009). Fluoride - induced hepatotoxicity is associated with an imbalance in the oxidant antioxidant systems of hepatic tissues causes hepatic dysfunction through free radicals mediated lipid peroxidation, DNA damage, inflammation, mitochondrial dysfunction and necrotic / apoptotic cell death (Wang et al., 2000 and Nabavi et al., 2012c).

The human diet, which contains many natural compounds in essential in protecting the body against the development of diseases. Human diet rich in vegetables and fruits have been associated with reduced rate of liver diseases (Alimi et al., 2012). Grapes are one of the most valued conventional fruits in the world 
Naglaa A. EL-Sheikh, Abeer A. Khed and Alaa H. Nofal

(Yang and Xian, 2013) and contain various nutrient elements such as vitamins, minerals, carbohydrates, edible fibers and phytochemicals. Grape juice is a fresh and nutritional beverage, highly appreciated worldwide, which its production is significantly increasing every year (Koyama et al., 2014). Phenolic compounds of the grape juice such as flavonoids, anthocyanins, tannins, phenolic acids, among others, are the main responsible for the beneficial healthy effects observed (Capanoglu et al., 2013). Montvale (2002) showed that red grape juice has hepatoprotective effect. Also, it is protective or therapeutic agent to attenuate organs damage and dysfunction in response to chemical toxins (Alnahdi and Ayaz, 2012). Black grape can provide protection against toxic effects (Lakshmi et al, 2013). Grape juices which are rich in polyphenol compounds with important antioxidant activity have protective effect against oxidative damage in the liver (Rodrigues et al,. 2013).
Therefore, the present study was carried out to evaluate the protective effects of grape juice varieties on liver toxicity induced by sodium fluoride in rats.

\section{MATERIALS \&METHODS}

\section{Materials:}

Grape fruit (vitis vinifera): The fresh green (white), red and black grape used in this study were purchased from the local market Shiben El-Kom City Menoufia Government, Egypt. Sodium Fluoride (Naf) was obtained from sigma Chemical Co. (St. Louis, Mo. USA). Kits for estimating biochemical analysis were purchased from Alkan Medical Company, St. ElDoky, Cairo, Egypt.

Animals: Forty eight adult male albino rats, Sprague Dawley stain, weighing $160 \pm 5 \mathrm{~g}$ were purchased from Medical Insects Research Institute, Doki, Cairo, Egypt.

\section{Methods:}

\section{Preparation of grape juice}

Fresh grape was washed with running water. Grape juice was prepared using National 
Naglaa A. EL-Sheikh, Abeer A. Khed and Alaa H. Nofal

juicer (MJ - 176N Japan) without adding water. The pure filtrated juice was stored at -20 ${ }^{\circ} \mathrm{C}$ until used.

\section{Experimental design}

Forty eight rats were housed separately in well aerated cages under hygienic laboratory conditions and fed standard diet for 7 days for adaptation according to AIN - 93 guidelines (Reeves et al., 1993). Then rats were randomly divided into five groups; the first: negative control group (6 rats) was fed standard diet. From 2 to 5 groups received the standard diet and a single oral dose of $10.3 \mathrm{mg} \mathrm{Naf}$ $/ \mathrm{kg}$ body weight for six weeks as described by Blaszczyk et al., (2011), the second group served as positive control group (6 rats), the third, fourth and fifth groups (12 rats /each) on the standard diet were divided into two sub groups (6 rats /each) and given a daily oral dose 5 and $10 \mu \mathrm{L} / \mathrm{g}$ body weight for 6 weeks of green (white), red and black grape juice respectively. The doses of green (white), red and black grape juice was determined according to Park $\boldsymbol{e} t$ al., (2003). .At the end of the experimental period rats were anesthetized after fasting for $12 \mathrm{~h}$ and non-heparinized blood samples were collected from the hepatic portal vein. Liver was taken and washed in saline solution until all blood was removed. The serum was collected from the blood samples by centrifugation and both serum and liver were kept frozen at $20^{\circ} \mathrm{C}$ till used for analysis.

\section{Chemical analysis:}

Total phenolics were determined according to the Folin - Ciocalteau method as described by Kaškonienè $\boldsymbol{e t}$ al., (2009). Total phenolic compounds were expressed as $\mathrm{mg}$ gallic acid equivalents /100 $\mathrm{ml}$ grape juice extract. Total Flavonoid was determined using a method described by $\mathrm{Xu}$ and chang (2007). Anthocyanin was determined according to Lako et al., (2007).

\section{Biochemical analysis:}

The serum levels of total lipids, total cholesterol (TC), triglyceride (TG) and high density lipoprotein (HDL.c) were determined by using 
Naglaa A. EL-Sheikh, Abeer A. Khed and Alaa H. Nofal

methods of Frings and Dunn (1979), Allain et al., (1974), Fossati and Prencipe (1982) and Demacker et al., (1980) respectively. The determination of low density lipoprotein cholesterol (LDL.c) and very low density lipoprotein cholesterol (VLDL.c) were carried out according to the methods of lee and Nieman (1996) as follows:

LDL.c $=$ Total cholesterol (HDL.c + VLDL.c).

VLDL.c $=\mathrm{TG} / 5$

Serum levels of alanine aninotransferase (ALT) and aspartate aminotransferase (AST) enzymes were assayed by the methods of Moss and Henderson (1999). The activity of alkaline phosphatase (Alp), gamma glutamine transferase (GGT) and total bilirubin (TB) were determined by the methods of Varley et al., (1980), Rosalki et al., (1970); Pearlman and lee (1974) respectively. Malonaldehyde (MDA), reduced glutathione (GSH Rd) and catalase (CAT) were assayed according to the methods described by Ohkawa et al., (1979), Moron et al., (1979) and sinha (1972) respectively.

\section{Histopathology examinations:}

Small specimens of the organs liver were taken from each experimental group, fixed in neutral buffered formalin, dehydrated in ascending concentration of ethanol $(70,80$ and $90 \%$ ), cleared in zylene and embedded in paraffin. Sections of 4-6 $\mu \mathrm{m}$ thickness were prepared and stained with hematoxylin and eosin according to Bancroft et al., (1996).

\section{Statistical analysis:}

Results were expressed as the mean \pm SD. Data for multiple variable comparisons were analyzed by one-way analysis of variance (ANOVA). For the comparison of significance between groups, Duncan's test was used as a post hoc test according to the statistical package program (Artimage and Berry, 1987).

\section{RESULTS \& DISCUSSION}

Total phenolics, total flavonoids and anthocyanins of fresh green (white), red and black grape juice is presented in Table (1). Black grape juice had the highest $(\mathrm{P} \leq 0.05) \quad$ total 
Naglaa A. EL-Sheikh, Abeer A. Khed and Alaa H. Nofal

phenolic, total flavonoids and anthocyanin contents followed by red grape juice, while green (white) grape juice was lowest $(\mathrm{P} \leq 0.05)$ in its content of total phenolic, total flavonoids and anthocyanin.. Grapes contain high amounts of phenolic, flavonoids and anthocyanins and acts as antioxidant (Yildirim $\boldsymbol{e t}$ al., 2005). Liang et al., (2014) reported that the content of Vitis vinifera grape cultivars of total phenolics ranged from 95.3 to $686.5 \mathrm{mg} / 100 \mathrm{~g}$ and flavonoids from 94.7 to $1055 \mathrm{mg} / 100 \mathrm{~g}$ .Also Mitic et al., (2011) showed that red fruit juices contain a high content of a different group of polyphenols, which have a potent antioxidant capacity and found that black grape juice had total phenolic (2230.4 mg gallic acid equivalent (GAE)/L) total flavonoids (368.48 $\mathrm{mg}$ catechin equivalent (CE)/L) and anthocyanins (208.67 $\mathrm{mg}$ cyaniding-3-glucosides equivalent (C3GE)/L). Toaldo et al., (2015) found that white grape juice had lower total phenolic content compared with red grape juice, whereas red grape juice was higher in anthocyanins content than white grape juice. The content of total phenolic of the grape juices was $1151 \mathrm{mg}$ GAE/L reported by Ishimoto et al., (2006). Kulcan et al., (2015) showed that total anthocyanin of extracted raw grape juice was $48.46 \mathrm{mg} / \mathrm{L}$. Moreover, total anthocyanin content varied from 181.2 to $716.4 \mathrm{mg} / 100 \mathrm{~g}$ fresh weight in grape varieties (Nile et al., 2015).

Data in Table (2) shows effect of green (white), red and black grape juice on serum lipid profile of hepatotoxicated rats. The results indicated that the levels of total lipids, cholesterol, triglyceride, VLDL.c and LDL.c showed significant $\quad(\mathrm{P} \leq 0.05)$ increase, while the level of HDL.c significantly $(\mathrm{P} \leq 0.05)$ decreased in the sodium fluoride groups compared to negative control group. Similar results were obtained by AbdelWahab (2013) reported that oral administration of $\mathrm{NaF}$ induced a significant increase in the level of total lipids, triglycerides and total cholesterol. Also, Hassan and Yousef (2009) found that the treatment with $\mathrm{NaF}$ caused significant increase in plasma 
Naglaa A. EL-Sheikh, Abeer A. Khed and Alaa H. Nofal

levels of total lipid, total cholesterol, triglyceride and LDL.c and decrease in HDL.c. The obtained results in the present study may be attributed to high levels of $\mathrm{NaF}$ lead to its accumulation in the liver leading to disturbance of lipid metabolism and in turn to the reported elevation the lipid profile (Grucka - Mamczar $\boldsymbol{e t}$ al., 2004).

Sodium fluoride intoxicated rats treated with green (white), red and black grape juice had significant reduction $\quad(\mathrm{P} \leq 0.05) \quad$ in cholesterol, triglyceride, VLDL.c and LDL.c levels compared to positive control group. Shanmuganayagam et al., (2007) reported that the daily consumption of grape juice at 70 $\mathrm{ml} / \mathrm{kg}$ /day decreased TC by $24 \%$ in rabbits. Administration of 10 $\mu \mathrm{l} / \mathrm{g}$ BW of green (white), 5,10 $\mu 1 / \mathrm{g}$ BW of red and black grape juice caused a significant reduction $(\mathrm{P} \leq 0.05)$ in total lipids level in sodium fluoride intoxicated rats, while HDL.c had an opposite trend. On the other hand, the levels of total lipids and LDL.c were lower
$(\mathrm{P} \leq 0.05)$ in sodium fluoride intoxicated rats treated with red and black grape juice than that of rats treated with green (white) grape juice. The study of Castilla et al., (2006) on healthy volunteers reported that concentrated red grape juice decreased LDL.c and increased HDL.c as well as in hemodialysis patients, polyphenol from red grape might lead to a possible modifying effect of lipoprotein metabolism through hepatic removal of cholesterol and an increase in its fecal excretion. Also, the present study showed that cholesterol, triglyceride and VLDL.c levels were significantly decreased $(\mathrm{P} \leq 0.05)$ in sodium fluoride intoxicated rats treated with 10 $\mu \mathrm{l} / \mathrm{g}$ BW of red and $5,10 \mu \mathrm{l} / \mathrm{g}$ BW of black grape juice compared with rats treated with green (white) grape juice. Vinson et al., (2001) found that grape juice decreased both TC and LDL.c in hamesters. However, treatments with 10 $\mu 1 / \mathrm{g}$ BW of black grape juice was more effective $(\mathrm{P} \leq 0.05)$ in reducing total lipids, cholesterol, triglyceride, VLDL.c and LDL.c levels in sodium fluoride intoxicated rats than those 
Naglaa A. EL-Sheikh, Abeer A. Khed and Alaa H. Nofal

treated with $10 \mu \mathrm{l} / \mathrm{g} \mathrm{BW}$ of green (white) grape juice, $5,10 \mu \mathrm{l} / \mathrm{g}$ BW of red grape juice and $5 \mu \mathrm{l} / \mathrm{g}$ BW of black grape juice. Moreover, there were no significant differences $(\mathrm{P}>0.05)$ in cholesterol, triglyceride, VLDL.c and LDL.c levels between black grape juice (10 $\mu 1 / \mathrm{g}$ BW) and negative control group. These results may due to high level of polyphenols (total phenolic, flavonoids and anthocyanin) present in grape juices. The action of polyphenols is associated with modulation of important physiological parameters such as plasma lipid profile, as a result of improved resistance towards oxidative stress, inflammation and endothelial dysfunction reported by Van Duynhoven $\boldsymbol{e t}$ al., (2010). Also, Alnahdi and Ayaz (2012) reported that phytochemical constituents of the grape juice have hypolipidemic potential action.

Effect of green (white), red and black grape juice on liver functions of hepatotoxicity rats is illustrated in Table (3). From the table it can be observed that treated rats with sodium fluoride caused significant increased $(\mathrm{P} \leq 0.05)$ in the activities of AST, ALT, ALP, GGT and TB. These results agreed with the findings of Abdel -Wahab (2013) who found that exposure to $\mathrm{NaF}$ (10 $\mathrm{mg} / \mathrm{kg} /$ day) for 4 weeks resulted in impairment in liver functions through significant increase in the activity of AST, ALT, ALP and total bilirubin by $73.1 \%$, $131.8 \%, 63.2 \%$ and $310.4 \%$ respectively.

Also,

Shanthakumari et al., (2004) recorded a significant increase in plasma ALT, AST and ALP of rats treated with $25 \mathrm{ppm}$ of fluoride for 8 and 16 weeks. The increased activities of serum AST, ALT and ALP indicate that the liver is susceptible to $\mathrm{NaF}$ induced toxicity. This increase could be attributed to hepatic damage resulting either in increased release of functional enzymes from biomembranes, or the increased synthesis as reported by Muthumani and Milton Prabu (2012). The elevation in the concentration of serum bilirubin in $\mathrm{NaF}$ - treated rats is consistent with the presence of hepatic damage (Nabavi et al., 2012c). 
Naglaa A. EL-Sheikh, Abeer A. Khed and Alaa H. Nofal

On the other hand, this study showed significant reduction $(\mathrm{P} \leq 0.05)$ of $\mathrm{AST}$, ALT, GGT,ALP and TB in sodium fluoride intoxicated rats after treating them with green(white) $(10 \mu \mathrm{l} / \mathrm{g} \mathrm{BW})$, red and black grape juices $(5,10$ $\mu 1 / \mathrm{g} \mathrm{BW})$. These results are in accordance with Pirinccioglu $\boldsymbol{e t}$ al., (2012) who reported that Okuzgozu grape juice significantly reduced the elevated activities of AST, ALT, ALP and TB and the improved the functional status of the liver. Administration of red grape juice $(2 \mathrm{ml} / \mathrm{rat})$ daily for 4 week by Alnahdi and Ayaz (2012) ameliorated the alteration in ALT and AST. However, in this study treated sodium fluoride intoxicated rats with black grape juice $(10 \mu \mathrm{l} / \mathrm{g} \quad \mathrm{BW})$ showed $(p \leq 0.05)$ low values of AST, ALT, GGT, ALP and TB compared to black grape juice $(5 \mu \mathrm{l} / \mathrm{g} \mathrm{BW})$ and red grape juice $(5,10 \quad \mu 1 / g \quad$ BW $) . \quad$. The procyanidins found in grapes can inhibit the apoptosis and damage of cells by oxygen free radicals (Li and Zhong, 2004). Therefore, the potent effect of grape juice may be the potent antioxidant effect of its polyphenols, including phenolic acids, anthocyanins and flavonoids (eg. proanthocyanidins), whereas phenolic compounds and flavonoids possess hepatoprotective activity in various experimental models as reported by Monagas et al, (2003) and sharma et al., (2012).

The results in Table (4) show effect of green (white), red and black grape juice on MDA, GSH.Rd and catalase activity in liver homogenates of hepatotoxicated rats. A significant elevation in the level of MDA and reduction in the activities of GSH.Rd and catalase in the liver were observed in sodium fluoride intoxicated rats when compared with negative control group $(\mathrm{p} \leq 0.05)$. Similar results were obtained by Abdel-Wahab (2013) and Nabavi et al, (2013) who reported that $\mathrm{NaF}$ intoxication resulted in a significant increase in lipid peroxidation as evidenced by the increased MDA level, whereas the activities of reduced glutathione (GSH.Rd) and 
Naglaa A. EL-Sheikh, Abeer A. Khed and Alaa H. Nofal

catalase (CAT) were reduced in hepatic tissues. Naf is known to produce oxidative damage in the liver by enhancing peroxidation of membrane lipids, a deleterious process solely carried out by free radicals (Pieta et al., 2012). Impairment of the antioxidant defense system is considered to be critically involved in NaFinduced toxic effects. This impairment interferes with the elimination of lipid peroxidation products and causes their accumulation in the cells leading to the damage of cell membranes reported by Abdel-Wahab (2013).

On the other hand, sodium fluoride intoxicated rats treated with red and black grape juice $(5,10 \mu \mathrm{l} / \mathrm{g}$ BW) had lower MDA in the liver than those rats treated with green(white) grape juice $(10 \mu \mathrm{l} / \mathrm{g} \quad \mathrm{BW}) \quad(\mathrm{P}<0.05)$. Also, treatment with $10 \mu \mathrm{l} / \mathrm{g} \mathrm{BW}$ of black grape juice was more effective in reducing MDA by $47,691 \%$ compared with positive control group $(\mathrm{P}<0.05)$. No Significant differences $(\mathrm{P}>0.05)$ was found in the levels of MDA among sodium fluoride intoxicated rats treated with 10 $\mu \mathrm{l} / \mathrm{g}$ BW of black grape juice and negative control group. The present results were in the same trend with Toaldo et al., (2015) who found that grape juice ingestion promoted a significant decrease in thiobarbituric acid reactive substances (TBARS) levels compared to the control intervention, demonstrating the protective effect of juice consumption against lipid peroxidation. Also, the reduction in MDA levels after treating Okuzgozu grape juice may be due to its high content of flavonoids and anthocyanin (Pirinccioglu et al., 2012) Furthermore, the activities of $\mathrm{GSH} \mathrm{Rd}$ and CAT were significantly increased $(\mathrm{P} \leq 0.05)$ in livers of sodium fluoride intoxicated rats treated with green (white) grape juice (10 $\mu 1 / \mathrm{g}$ BW), red and black grape juice $(5, \quad 10 \mu \mathrm{l} / \mathrm{g} \quad \mathrm{BW})$ as compared with positive control group. However, sodium fluoride intoxicated rats treated with $10 \mu \mathrm{l} / \mathrm{g} \mathrm{BW}$ of black grape juice had high activity of GSH $\mathrm{Rd}$ and CAT compared to other concentrations of different types grape juice $(\mathrm{P} \leq 0.05)$. Lakshmi et al., (2013) reported that black 
Naglaa A. EL-Sheikh, Abeer A. Khed and Alaa H. Nofal

grape extract showed significant increase in GSH Rd and CAT activities as well as decrease in MDA levels in rat liver compared with lead control group. Treatment with organic and conventional purple grape juices conferred protection against lipid and protein oxidative damage through limited increase in TBARS levels and inhibited reduction of catalase activity in the liver (Rodrigues et al., 2013).. All of these results are in accordance with the content of bioactive polyphenol compounds in grape juice, which could play a role against lipid peroxidation. Gris et al., (2013) showed that the improvement of the antioxidative defense was promoted by grape juice ingestion due to the capacity of phenolic compounds that eliminate free radicals and prevent lipid peroxidation by scavenging peroxyl radicals in phospholipids membrane of the cells. Black grape juice was capable of reducing carbonyl and lipid peroxidation levels in the liver and induced better antioxidant effects because of its content of anthocyanin (Dani $\boldsymbol{e t}$ al., 2008).

Photo (1) shows effect of green (white), red and black grape juices on histological examination of liver tissues in hepatotoxicity rats. Histopathological examination of the liver of normal control rats revealed normal histological structure without any pathological lesions (H\&EX 400) (Photo1A). While the examination of sodium fluoride intoxicated rats liver tissues showed congestion of the control veins and hepatic blood vessels with sinusoidal dilatation. The parenchymal hepatocytes showed various degenerative changes mostly centrilobular including granular and vacuolar degeneration with activated kupffer cells and necrosis of the hepatocytes without any nuclear structure (Photo 1B). Histological sections of livers in Naf treated rats revealed hepatic injury manifested by mononuclear cell aggregation around the congestive blood vessel and bile duct in the buccal area together with dilatation of the sinusoid reported by

Khudiar and Aldabaj (2015). 
Naglaa A. EL-Sheikh, Abeer A. Khed and Alaa H. Nofal

Also, Atmaca et al., (2014) showed that fluoride intoxication was associated with severe histopathological changes in liver tissues.

As shown in (Photo 1C) portal area in liver of sodium fluoride intoxicated rats treated with $5 \mu 1 / \mathrm{g} \mathrm{BW}$ of green (white) grape juice showed mild fibroplasia, mild bile duct hyperplasia and inflammatory cells infiltration. The changes in rats treated with $5 \mu \mathrm{l} / \mathrm{g} \mathrm{BW}$ of red grape juice were focal area of necrotic hepatocytes replaced by mononuclear inflammatory cells (Photo 1D). However, only sinusoidal dilatation and mild hepatocellular degeneration were observed in liver of sodium fluoride intoxicated rats treated with $5 \mu \mathrm{l} / \mathrm{g}$ BW of black grape juice (Photo 1E). On the other hand, fluoride rats treated with $10 \mu \mathrm{l} / \mathrm{g}$ BW of green (white) grape juice revealed mild hyperplasia of the bile duct with few inflammatory cells infiltration (Photo 1F).. Moreover, the liver of sodium fluoride rats treated with $10 \mu \mathrm{l} / \mathrm{g}$ BW of red and black grape juice showed mild kupffer cell activation and few necrotic cells but with normal organization of the hepatic cords (Photo $1 \mathrm{G}$ and H). So the histological examination of liver tissues of sodium fluoride intoxicated rats treated with $10 \mu \mathrm{l} / \mathrm{g} \mathrm{BW}$ of green (white), red and black grape juices had nearly the same moderate degree of restorative effect on the hepatic structure against the harmful effect of NaF. Pirinccioglu et al., (2012) found that administration of grape juice resulted in the restoration of the pathology of the liver tissue to some extent. Grape juices present important hepatic and systemic protection effects against oxidative damages in rats (Rodrigues $\boldsymbol{e t}$ al, 2013). Quercetin (the most abundant flavonoids in black grape juice) was reported as a protective agent against oxidative damage in rat hepatocytes reported by Liu $\boldsymbol{e t}$ al., (2009), Whereas flavonoids effectively prevent lipid peroxidation and protein oxidation in rats liver mitochondria (Londhe et al., 2009). 
Naglaa A. EL-Sheikh, Abeer A. Khed and Alaa H. Nofal

CONCLUSION

These results have suggested that red and black grape juice contain a high content of different group of polyphenols, which have a potent antioxidant capacity and potent effects against the toxicity of $\mathrm{NaF}$ through inhibition of the development of fluoride induced hepatotoxicity in rats. Accordingly, care must be taken into account to ovoid mammalian and human exposure to $\mathrm{NaF}$ and attention should be paid to sources of it in foods and water as well as occupational sources.

\section{References}

\section{Abdel-Wahab WM (2013):}

Protective effect of thymoquinone on sodium fluoride-induced hepatotoxicity and oxidative stress in rats, The Journal of Basic and Applied Zoology, 66:263270.

Alimi H; Hfaeidh N; Mbarki S; Bouoni Z; Sakly M and Ben Rouma $K$ (2012):

Evaluation of Opuntia ficus indica $f$. inermis fruit juice hepatoprotective effect upon ethanol toxicity in rats. Gen Physiol Biophys., 31(3): 335-342.

Allain CC; Richmond Nand Rosechloy P (1974):

Cholesterol enzymatic colorimetric test, Chem. Clin., 19(20): 1350-1361.

Alnahdi H S and Ayaz N O (2012):

Beneficial impact of red grape juice against tissue damage induced by ethanol toxicity in rats, Zoology, 31A (2):51-64.

Artimage GY and Berry WG (1987):

Statistical Methods 7th Ed. Ames, Iowa State University Press, 39-63.

Atmaca N; Atmaca HT; Kanici A and Anteplioglu $T$ (2014):

Protective effect of resveratrol on sodium 
A Comparative Study Between Grape (Vitis vinifera) Juice Varieties on Liver Toxicity Induced by Sodium Fluoride in Adult Rats

Naglaa A. EL-Sheikh, Abeer A. Khed and Alaa H. Nofal

fluoride-induced oxidative stress, hepatotoxicity and neurotoxicity in rats. Food Chem. Toxico., 70:191197.

Bancroft D; Steven A and Turner R (1996):

Theory and Practice of Histological Techniques 4th Churchill Livingstone, Edinburgh, London, Melbourne.

Blaszczyk I; Birkner E and Kasperczy $S$ (2011):

Influence of methionine on toxicity of fluoride in the liver of rats. Biol. Trace Elem. Res., 139: 325-331.

Bouaziz H; Ben Amara I; Essefi M; Croute $F$ and Zeghal N (2010):

Pesticide Biochemistry and Physiology .96: 2429.

Capanoglu E; Vos RCHD; Hall RD; Boyacioglu D and Beekwilder J (2013): Changes in polyphenol content during production of grape juice concentrate.
Food Chemistry, 139: 521526.

Castilla P; Echarri R; Dávalos A; Cerrato F; Ortega H; Teruel J L; Lucas MF; Gomez-Coronado D; Ortuno $J$ and lasuncion M (2006):

Concentrated red grape juice exerts antioxidant, hypolipidemic, and antiinflammatory effects in both hemodialysis patients and healthy subjects. Am. J. Clin. Nutr., 84:252e62.

Dani C; Oliboni LS; Pasquali MA; Oliveira MR; Umezu FM; Salvador M; Moreira JC and Henriques J A (2008):

Intake of purple grape juice as a hepatoprotective agent in Wistar rats, $J$. Med Food, 11: 127-132

Demacker PM; Von-Janssen HE; Hifman AM; Vant's Lear $A$ and Jansen AP (1980):

Measurement of high density lipoprotein cholesterol in serum. Comparison of six 
A Comparative Study Between Grape (Vitis vinifera) Juice Varieties on Liver Toxicity Induced by Sodium Fluoride in Adult Rats

Naglaa A. EL-Sheikh, Abeer A. Khed and Alaa H. Nofal

isolation methods

combined with enzymatic cholesterol analysis. Clin.

Chem. 26: 1780-1789.

Fossati $P$ and Prencipe I (1982):

Serum triglycerides

determination

colorimetrically with an enzyme that produce hydrogen peroxide, Clin. Chem. 28: 2077-2083.

Frings CS and Dunn RT (1979):

Colorimetric method for determination total serum lipids based on the sulphopospho vanillin reaction. Am. J. Clin. Pathol., 53: 89-91.

Gao Q; Liu Y J and Guan Z Z (2009b):

Decreased learning and memory ability in rats with fluorosis: increased oxidative stress and reduced cholinesterase activity in the brain. Fluoride 42: 277-285

Gris EF; Mattivi F; Ferreira EA; Vrhovsek U; Filho
DW; Pedrosa RC and Bordignon-Luiz MT (2013):

Phenolic profile and effect of regular consumption of Brazilian red wines on in vivo antioxidant activity, Journal of Food Composition and Analysis, 31: 31-40.

Grucka-Mamczar E; Birkner E; Kasperczyk S; Kasperczyk A; Chlubek D and Samujlo D (2004): Lipid balance in rats with fluoride induced hyperglycemia. Fluoride. 37:195-200.

Grucka-Mamczar E; ZalejskaFiolka J; Chlubek D; Kasperczyk S; Błaszczyk U; Kasperczyk A; Swietochowska $E$ and Birkner E (2009):

Tea influence of sodium fluoride and caffeine on the activity of antioxidative enzymes and the concentration of malondialdehyde in rat liver, Fluoride. 42: 105109. 
A Comparative Study Between Grape (Vitis vinifera) Juice Varieties on Liver Toxicity Induced by Sodium Fluoride in Adult Rats

Naglaa A. EL-Sheikh, Abeer A. Khed and Alaa H. Nofal

Hassan HA and Yousef MI (2009):

Mitigating effects of antioxidant properties of black berry juice on sodium fluoride induced hepatotoxicity and oxidative stress in rats. Food Chem. Toxico., 47:2332-2337.

\section{He LF and Chen JG (2006):}

DNA damage, apoptosis and cell cycle changes induced by fluoride in rat oral mucosal cells and hepatocytes, World J. Gastroenterol. 12:11441148.

Ishimoto EY; Ferrari CK; Bastos DH and Torres EA (2006):

In vitro Antioxidant activity of Brazilian wines and grape juices. J. Wine Res., 17(2): 107-115.

Kaškonienė $\mathbf{V}$; Maruška $A$; Kornyšova O; Charczun $\mathrm{N}$; Ligor $M$ and Buszewski B (2009):

Quantitative and qualitative determination of phenolic compounds in honey.

Chemine

Technologija, 3: 74-80.

Khudiar KK and Aldabaj AMA (2014):

Effect of high concentration of sodium fluoride on serum lipid profile of male rabbits: Hypolipidemic effect of grape seed oil. Online Int. Interdisciplin. Res. J. 5:17-24.

Khudiar KK and Aldabaj AMA (2015):

Effect of grape seed oil on hepatic function in adult male rabbits treated with sodium fluoride (Part-II). Advances in Animal and Veterinary Sciences, 3(10): 550-558.

Koyama R; de Assis AM; Yamamoto LY; Borges WF; de Sa Borges R; Prudencio SH and Roberto SR (2014):

Exogenous abscisic acid increases the anthocyanin concentration of berry and juice from 'Isabel' grapes (Vitis labrusca L.). Hort Science, 49: 460-464. 
A Comparative Study Between Grape (Vitis vinifera) Juice Varieties on Liver Toxicity Induced by Sodium Fluoride in Adult Rats

Naglaa A. EL-Sheikh, Abeer A. Khed and Alaa H. Nofal

Kulcan AA; Öziyci HR; Tetik $N$ and Karhan M (2015): Changes in turbidity, total phenolic and anthocyanin contents of clear red grape juice during processing. GIDA., 40(6): 311-317.

Lako J; Trenerry VC; Wahlqvist $\mathrm{M}$; Wattanapenpaiboon $\mathbf{N}$; Sotheeswaran $S$ and Premier R (2007):

Phytochemical flavonols, carotenoids and the antioxidant properties of a wide selection of Fijian fruit, vegetables and other readily available foods. Food Chemistry, 101: 1727-1741.

\section{Lakshmi BV; Sudhakar M and} Aparna M (2013):

Protective potential of black grapes against lead induced oxidative stress in rats. Environmental Toxicology and pharmacology, 35:61-68.

Lee $R$ and Nieman D (1996):
Nutrilional. Assessment. 2 nd, Mosby, Missouri, USA.

\section{Li L and Zhong J (2004):}

$\begin{aligned} & \text { Effect of grape } \\ & \text { procyanidins on } \\ & \text { apoptosis } \\ & \text { mitochondrial }\end{aligned}$
transmembrane potential of thymus cells, Journal of Hygiene research, 33: 191-194.

Liang Z; Cheng L; Zhong GY and Liu R H (2014):

Antioxidant and Antiproliferative activities of twenty- four Vitis vinifera grapes. J. Pone. 9(8): 105-146.

Liu G; Chai C and Cui L (2003):

Fluoride causing abnormally elevated serum nitric oxide levels in chicks. Environ. Toxicol. Pharmacol. 13: 199-204.

Liu S; Hou W; Yao P; Zhang B; Sun S; Nussler A K and Liu L (2009):

Quercetin protects against ethanol-induced oxidative 
A Comparative Study Between Grape (Vitis vinifera) Juice Varieties on Liver Toxicity Induced by Sodium Fluoride in Adult Rats

Naglaa A. EL-Sheikh, Abeer A. Khed and Alaa H. Nofal

damage in rat primary hepatocytes. Toxicol In Vitro.

Mitic MN; Obradovic MV; Kostic DA; Naskovic DC and Micic R J (2011):

Phenolics content and antioxidant capacity of commercial red fruit juices. Hem. Ind., 65(5): 611-619.

Monagas M; Gomez-Cordoves C; Bartolome B; Laureano O; Ricardo DA and Silva JM (2003):

Monomeric, oligomeric, and polymeric flavan-3-ol composition of wines and grapes from Vitis vinifera L. Cv. Graciano, Tempranillo, and Cabernet Sauvignon. J. Agric. Food Chem., 51: 6475-6481

Montvale NJ (2002):

PDR for Herbal Medicines, second ed. Medical Economics, PP.362-363.

Moron MS; Despierre JW and Minnervik B (1979):
Levels of glutathione, glutathione reductase and glutathione S-transferase activities in rat lung and liver. Biochim. Biophys. Acta., 582:67-78.

Moss DW and Henderson AR (1999):

Clinical enzymology. in: Burtis CA, Ashwood, E.R., editors. Tietz textbook of clinical chemistry. 3rd ed. Philadephia: WB Saunders company; PP. 617-721.

Muthumani $M$ and Milton Prabu S (2012):

Silibinin potentially protects arsenic induced oxidative hepatic dysfunction in rats. Toxicol. Mech. Methods, 22: 277-288.

Nabavi SF; Moghaddam AH; Eslami $S$ and Nabavi $S$ $M$ (2012):

Biological Trace Element Research. 145:369-374.

Nabavi SF; Nabavi SM; Abolhasani

F; 
A Comparative Study Between Grape (Vitis vinifera) Juice Varieties on Liver Toxicity Induced by Sodium Fluoride in Adult Rats

Naglaa A. EL-Sheikh, Abeer A. Khed and Alaa H. Nofal

Moghaddam AH and

Eslami S (2012a):

Cytoprotective effects of curcumin on sodium

fluoride-induced

intoxication in rat erythrocytes. Bull.

Environ. Contam. Toxicol., $88: 486-490$

Nabavi SF; Habtemariam S; Jafari M; Sureda A and Nabavi S M (2012b.):

Protective role of gallic acid on sodium fluoride induced oxidative stress in rat brain. Bull. Environ. Contam. Toxicol., doi:10. 1007/s00128-012-0645-4

Nabavi SM; Nabavi SF; Eslami $S$ and Moghaddam A H ( 2012c):

In vivo protective effects of quercetin against sodium fluoride-induced oxidative stress in the hepatic tissue. Food Chem., 132: 931-935.

Nabavi SF; Nabavi SM; Habtemariam S; Moghaddam AH; Suredo
A; Daglia M; Jafari M and Latifi AM (2013):

Hepatoprotective effect of gallic acid isolated from Peltiphyllum peltatum against sodium fluoride induced oxidative stress. Industrial Crops and products, 44: 50-55.

Nile SH; Kim DH and Keum YS (2015):

Determination of anthocyanin content and antioxidant capacity of different grape varieties. Ciência Téc. Vitiv. 30(2): 60-68.

Ohkawa H; Ohishi N and Yagi K (1979):

Assay for lipid peroxides in animal tissues by thiobarbituric acid reaction. Anal Biochem., 95:351-358.

Park YK; Park E; Kim JS and Kang MH (2003):

Daily grape juice consumption reduces oxidative DNA damage and plasma free radical levels in healthy Koreans. 
A Comparative Study Between Grape (Vitis vinifera) Juice Varieties on Liver Toxicity Induced by Sodium Fluoride in Adult Rats

Naglaa A. EL-Sheikh, Abeer A. Khed and Alaa H. Nofal

Mutation Research, 529: 77-86.

Pearlman FC and Lee RTY (1974):

Detection and
measurement of total
bilirubin in serum, with
use of surfactants as
solubilizing agents.
Clinical Chemistry 20,
$447-453$.

Pieta BS; Bielec B; Birkner K and Birkner $\mathrm{E}$ (2012):

The influence of vitamin $\mathrm{E}$ and methionine on the activity of enzymes and the morphological picture of liver of rats intoxicated with fluoride. Food Chem. Toxicol., 50:972-978.

Pirinccioglu M; Kızl G; Kızl M; Ozdemir G; Kanay Z and Ketani MA (2012):

Protective effect of Okuzgozu (Vitis vinifera L. cv.) grape juice against carbon tetrachloride induced oxidative stress in rats. Food Funct., 3:668673.
Reeves PG; Nielsen FH and Fahey GC (1993):

AIN-93 purified diets for laboratory rodents: final report of the American Institute of Nutrition adhoc writing committee on the reformulation of the AIN76 A rodent diet. J. Nutr., 123: 1939-1951.

Rodrigues AD; Scheffel TB ; Scola G; Dos Santos M T; Fank B; Dani C; Vanderlinde $\quad R$; Henriques JA; Coitinho AS and Salvador $M$ (2013):

Purple grape juices prevent pentylenetetrazolinduced oxidative damage in the liver and serum of wistar rats. Nutri. Research, 33: 120-125.

Rosalki SB; Rav D; Lchman D and Prentice $M(1970)$ :

Determination of serum gamma-glutamyl

transpeptidase activity and its clinical applications. Ann Clin Biochem 7:143-7 
A Comparative Study Between Grape (Vitis vinifera) Juice Varieties on Liver Toxicity Induced by Sodium Fluoride in Adult Rats

Naglaa A. EL-Sheikh, Abeer A. Khed and Alaa H. Nofal

Shanthakumari D; Srinivasalu $S$ and Subramanian $S$ (2004):

Effect of fiuoride intoxication on lipidperoxidation and antioxidant status in experimental rats. Toxicology, 204: 214-228.

Shanmuganayagam

D;

Warner TF; Krueger CG; Reed JD and Folts J (2007):

Concord grape juice attenuates platelet aggregation, serum cholesterol and development of atheroma in hypercholesterolemic rabbits, Atherosclerosis, 190:135-142.

Sharma A; Sangameswaran B; Mahajan SC and Manmeet Singh Saluja MS (2012):

Protective effects of Sida veronicaefolia against ethanol induced hepatotoxicity in experimental animals. Phytopharmacol., $3(1)$ : 137-144.
Sinha AK (1972):

Colorimetric assay of catalase. Ann Biochem 47:389-94.

Toaldo IM; Cruz FA; Alves T; de Gois JS; Borges DL; Cunha HP; da Silva EL and Bordignon-Luiz MT (2015) :

Bioactive potential of Vitis labrusca L. grape juices from the southern region of Brazil: Phenolic and elemental composition and effect on lipid peroxidation in healthy subjects. Food Chemistry, 173: 527-535.

Van Duynhoven JP; Vaughan EE; Jacobs DM; Kemperman RA; Van Velzen EJJ; Gross G; Roger LC; Possemiers S; Smilde A K; Doré J; Westerhuis JA and Wiele TV (2010):

Microbes and Health Sackler Colloquium: Metabolic fate of polyphenols in the human superorganism.

Proceedings of the National Academy of 
Naglaa A. EL-Sheikh, Abeer A. Khed and Alaa H. Nofal

Sciences of the United

States of America, 108: 4531-4538.

Varley H; Gewenlock A and Bell M (1980):

Practical clinical biochemistry, Vol. 1, $5^{\text {th }}$ ed. Pp.741:897. London; Williams

Heinemen

Medical books, Ltd

Vinson JA; Teufel $\mathrm{K}$ and Wu N (2001):

Red wine, dealcoholized red wine, and especially grape juice, inhibit atherosclerosis in a hamster model, Atherosclerosis 2001, 156, 67-72

Wang Y N; Xiao KQ; Liu J L ; Dallner $G$ and Guan $Z$ Z.(2000):

Effect of long term fluoride exposure on lipid composition in rat liver. Toxicology,146, 161- 169. antioxidant activities of legumes as affected by extraction solvents. J. Food Sci., 72: 159-166.

\section{Yang J and Xiao XY (2013):}

Grape phytochemicals and associated health benefits. Critical Reviews in Food Science and Nutrition, 53(11): 1202-1225

Yildirim H K; Akçay YD; Güvenç U; Altindisli A and Sözmen EY (2005):

Antioxidant activities of organic grape, pomace, juice,must, wine and their correlation with phenolic content. Int. J. Food Sci. Technol., 40, 133-142.

Xu BJ and Chang SKC (2007):

A comparative study on phenolic profiles and 
A Comparative Study Between Grape (Vitis vinifera) Juice Varieties on Liver Toxicity Induced by Sodium Fluoride in Adult Rats

Naglaa A. EL-Sheikh, Abeer A. Khed and Alaa H. Nofal

Table (1): Total phenolic, total flavonoids and anthocyanins of fresh green (white), red and black grape juice.

\begin{tabular}{|l|c|c|c|}
\hline \multicolumn{1}{|c|}{ Parameters } & $\begin{array}{c}\text { Green } \\
\text { (white) grape } \\
\text { juice }\end{array}$ & $\begin{array}{c}\text { Red grape } \\
\text { juice }\end{array}$ & $\begin{array}{c}\text { Black } \\
\text { grape juice }\end{array}$ \\
\hline $\begin{array}{l}\text { Total phenolic } \\
(\mathbf{m g} \text { gallic acid/100ml) }\end{array}$ & $53.41^{\mathrm{c}} \pm 2.81$ & $125.6^{\mathrm{b}} \pm 2.8$ & $172.8^{\mathrm{a}} \pm 3.01$ \\
$\begin{array}{l}\text { Total Flavonoids } \\
(\mathbf{m g} \text { catechin/100 } \mathbf{~ m l})\end{array}$ & $14.75^{\mathrm{c}} \pm 0.75$ & $22.74^{\mathrm{b}} \pm 1.87$ & $32.42^{\mathrm{a}} \pm 3.49$ \\
$\begin{array}{l}\text { Anthocyanins } \\
(\mathbf{m g} \text { cyanidin-3- } \\
\text { glucoside/100ml) }\end{array}$ & $0.89^{\mathrm{c}} \pm 0.34$ & $72.47^{\mathrm{b}} \pm 2.65$ & $95.34^{\mathrm{a}} \pm 0.79$ \\
\hline
\end{tabular}

Each value in the table is the mean \pm standard deviation of three replicates. 
A Comparative Study Between Grape (Vitis vinifera) Juice Varieties on Liver Toxicity Induced by Sodium Fluoride in Adult Rats

Naglaa A. EL-Sheikh, Abeer A. Khed and Alaa H. Nofal

Table (2): Effect of green (white), red and black grape juice on serum lipid profile of hepatotoxicity rats

\begin{tabular}{|c|c|c|c|c|c|c|c|c|}
\hline \multirow[b]{3}{*}{ Parameters } & \multirow[t]{3}{*}{ Negative control } & \multicolumn{7}{|c|}{ Sodium Fluoride groups } \\
\hline & & \multirow[t]{2}{*}{ Positive control } & \multicolumn{2}{|c|}{ Green (white) grape juice } & \multicolumn{2}{|c|}{ Red grape juice } & \multicolumn{2}{|c|}{ Black grape juice } \\
\hline & & & $(5 \mu \mathrm{l} / \mathrm{g} \mathrm{BW})$ & $(10 \mu \mathrm{l} / \mathrm{g} \mathrm{BW})$ & $(5 \mu \mathrm{l} / \mathrm{g} \mathrm{BW})$ & $(10 \mu \mathrm{l} / \mathrm{g} \mathrm{BW})$ & $(5 \mu \mathrm{l} / \mathrm{g} \mathrm{BW})$ & $(10 \mu \mathrm{l} / \mathrm{g} \mathrm{BW})$ \\
\hline Total lipids (mg/dl) & $421.96^{f} \pm 11.03$ & $604.71^{\mathrm{a}} \pm 10.24$ & $595.5^{\mathrm{a}} \pm 14.49$ & $569.67^{b} \pm 9.42$ & $540.5^{c} \pm 9.65$ & $502.08^{d} \pm 10.12$ & $493.5^{\mathrm{d}} \pm 8.67$ & $440.17^{\mathrm{e}} \pm 9.54$ \\
\hline Cholesterol (mg/dl) & $97.38^{f} \pm 1.34$ & $170.33^{\mathrm{a}} \pm 7.5$ & $162.67^{b} \pm 6.15$ & $140.83^{c} \pm 9.02$ & $134.17^{\mathrm{c}} \pm 7.63$ & $109.33^{\mathrm{e}} \pm 5.47$ & $117.67^{d} \pm 5.2$ & $101.33^{\mathrm{f}} \pm 6.02$ \\
\hline Triglyceride (mg/dl) & $66.86^{f} \pm 2.18$ & $114.03^{\mathrm{a}} \pm 3.96$ & $104.42^{b} \pm 4.91$ & $93.47^{c} \pm 3.66$ & $91.95^{c} \pm 5.32$ & $77.33^{\mathrm{e}} \pm 3.78$ & $84.46^{\mathrm{d}} \pm 2.24$ & $70.21^{f} \pm 1.84$ \\
\hline HDL.c (mg/dl) & $56.97^{\mathrm{a}} \pm 1.67$ & $13.75^{\mathrm{g}} \pm 1.33$ & $20.92^{f} \pm 2.87$ & $26.25^{\mathrm{e}}+4.19$ & $28.17^{\mathrm{e}} \pm 4.49$ & $42.38^{c} \pm 4.47$ & $36.39^{d} \pm 3.94$ & $52.38^{b} \pm 4.47$ \\
\hline VLDL.c (mg/dl) & $13.37^{\mathrm{f}} \pm 0.44$ & $22.81^{\mathrm{a}} \pm 0.79$ & $20.88^{b} \pm 0.98$ & $18.69^{c} \pm 0.73$ & $18.39^{c} \pm 1.06$ & $15.47^{\mathrm{e}} \pm 0.76$ & $16.89^{d} \pm 0.45$ & $14.04^{f} \pm 0.36$ \\
\hline LDL.c (mg/dl) & $27.04^{g} \pm 0.77$ & $133.77^{a} \pm 7.79$ & $120.87^{b} \pm 7.25$ & $95.89^{c} \pm 7.79$ & $87.61^{d} \pm 7.77$ & $51.48^{f} \pm 6.16$ & $64.39^{e} \pm 4.93$ & $34.91^{\mathrm{g}} \pm 8.31$ \\
\hline
\end{tabular}

Values in the table were expressed as means $\pm S D$. Different letters in the same now were significantly different $(p \leq 0.05)$.

HDL.c : high density lipoprotein cholesterol, VLDL.c : very low density lipoprotein cholesterol, LDL.c : low density lipoprotein cholesterol. 
A Comparative Study Between Grape (Vitis vinifera) Juice Varieties on Liver Toxicity Induced by Sodium Fluoride in Adult Rats

Naglaa A. EL-Sheikh, Abeer A. Khed and Alaa H. Nofal

Table (3): Effect of green (white), red and black grape juice on liver function of hepatotoxicity rats.

\begin{tabular}{|c|c|c|c|c|c|c|c|c|}
\hline \multirow[b]{3}{*}{ Parameters } & \multirow[t]{3}{*}{ Negative control } & \multicolumn{7}{|c|}{ Sodium Fluoride groups } \\
\hline & & \multirow[t]{2}{*}{ Positive control } & \multicolumn{2}{|c|}{ Green (white) grape juice } & \multicolumn{2}{|c|}{ Red grape juice } & \multicolumn{2}{|c|}{ Black grape juice } \\
\hline & & & $(5 \mu \mathrm{l} / \mathrm{g} \mathrm{BW})$ & $(10 \mu \mathrm{l} / \mathrm{g} \mathrm{BW})$ & $(5 \mu \mathrm{l} / \mathrm{g} \mathrm{BW})$ & $(10 \mu \mathrm{l} / \mathrm{g} \mathrm{BW})$ & $(5 \mu \mathrm{l} / \mathrm{g} \mathrm{BW})$ & $(10 \mu \mathrm{l} / \mathrm{g} \mathrm{BW})$ \\
\hline AST (U/I) & $70.83^{g}+2.4$ & $125.33^{\mathrm{a}} \pm 12.08$ & $120.33^{\mathrm{a}} \pm 2.8$ & $109.5^{b} \pm 2.43$ & $103^{c} \pm 2.61$ & $93.83^{d} \pm 3.06$ & $\begin{array}{c}86.17^{\mathrm{e}} \pm \\
3.19\end{array}$ & $77.5^{f} \pm 1.87$ \\
\hline $\operatorname{ALT}(\mathrm{U} / \mathrm{I})$ & $30.09^{f} \pm 2.35$ & $67.5^{\mathrm{a}} \pm 3.62$ & $56.5^{\mathrm{b}} \pm 3.08$ & $55.17^{b} \pm 3.54$ & $48.5^{c} \pm 4.28$ & $42.62^{\mathrm{d}} \pm 2.42$ & $41.5^{\mathrm{d}} \pm 2.43$ & $36.17^{\mathrm{e}} \pm 3.76$ \\
\hline GGT (U/I) & $33.67^{\mathrm{f}} \pm 2.88$ & $80.02^{\mathrm{a}} \pm 2.64$ & $78.33^{a} \pm 3.14$ & $72.11^{b} \pm 2.54$ & $63.67^{c} \pm 2.16$ & $51.17^{d} \pm 2.93$ & $53.5^{\mathrm{d}} \pm 3.83$ & $40.31^{e} \pm 3.48$ \\
\hline $\operatorname{ALP}(\mathrm{U} / \mathrm{I})$ & $116.13^{g} \pm 2.58$ & $182.88^{a} \pm 2.91$ & $178.83^{a} \pm 3.19$ & $\frac{166.33^{\mathrm{b}} \pm}{5.65}$ & $161.5^{c} \pm 4.09$ & $\begin{array}{c}150.17^{\mathrm{d}} \pm \\
3.97\end{array}$ & $\begin{array}{c}142.88^{\mathrm{e}} \pm \\
3.4\end{array}$ & $128.44^{\mathrm{f}} \pm 2.02$ \\
\hline TB (mg/dl) & $0.42^{d} \pm 0.1$ & $0.99^{a} \pm 0.3$ & $0.93^{a} \pm 0.36$ & $0.85^{\mathrm{ab}} \pm 0.04$ & $0.74^{b c} \pm 0.31$ & $0.69^{c} \pm 0.02$ & $0.62^{c} \pm 0.03$ & $0.48^{d} \pm 0.04$ \\
\hline
\end{tabular}

Values in the table were expressed as means $\pm S D$. Different letters in the same now were significantly different $(p \leq 0.05)$.

AST: aspartate aminotransferase, ALT : alanine aminotransferase, ALP : alkaline phosphatase, GGT : gamma glutamine transferase, TB : total bilirubin. 
A Comparative Study Between Grape (Vitis vinifera) Juice Varieties on Liver Toxicity Induced by Sodium Fluoride in Adult Rats

Naglaa A. EL-Sheikh, Abeer A. Khed and Alaa H. Nofal

Table (4): Effect of green (white), red and black grape juice on MDA, GSH and Catalase activity in liver homogenate of hepatotoxicity rats

\begin{tabular}{|c|c|c|c|c|c|c|c|c|}
\hline \multirow[b]{3}{*}{ Parameters } & \multirow[t]{3}{*}{ Negative control } & \multicolumn{7}{|c|}{ Sodium Fluoride groups } \\
\hline & & \multirow[t]{2}{*}{ Positive control } & \multicolumn{2}{|c|}{ Green (white) grape juice } & \multicolumn{2}{|c|}{ Red grape juice } & \multicolumn{2}{|c|}{ Black grape juice } \\
\hline & & & 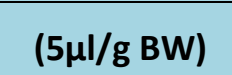 & $(10 \mu \mathrm{l} / \mathrm{g}$ BW) & 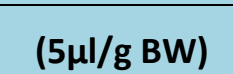 & $(10 \mu \mathrm{l} / \mathrm{g}$ BW) & $(5 \mu \mathrm{l} / \mathrm{gBW})$ & $(10 \mu \mathrm{l} / \mathrm{g}$ BW) \\
\hline MDA (Mmol / g.tit) & $27.16^{e} \pm 8.93$ & $61.14^{\mathrm{a}} \pm 3.44$ & $59.24^{a} \pm 2.71$ & $54.19^{b} \pm 3.04$ & $49.26^{c} \pm 3.38$ & $43.26^{d} \pm 3.71$ & $39.72^{d} \pm 1.57$ & $31.98^{\mathrm{e}} \pm 2.11$ \\
\hline GSH Rd (Mg / g.tit) & $17.45^{\mathrm{a}} \pm 1.49$ & $7.86^{f} \pm 1.28$ & $8.01^{f} \pm 0.64$ & $9.49^{\mathrm{e}} \pm 1.31$ & $11.02^{d} \pm 0.85$ & $12.55^{\mathrm{c}} \pm 1.14$ & $12.28^{c d} \pm 1.48$ & $14.95^{b} \pm 1.15$ \\
\hline CAT (Mmol/ g.tit) & $80.7^{a} \pm 1.8$ & $47.2^{f} \pm 3.04$ & $49.35^{f} \pm 1.91$ & $52.09^{e} \pm 2.78$ & $54.73^{\mathrm{e}} \pm 1.8$ & $61.09^{d} \pm 1.58$ & $65.64^{\mathrm{c}} \pm 2.1$ & $75.09^{b} \pm 3.03$ \\
\hline
\end{tabular}

Values in the table were expressed as means \pm SD. Different letters in the same Raw were significantly different $(p \leq 0.05)$.

MDA: malonaldehyde, GSH.Rd: reduced glutathione, CAT: catalase. 
A Comparative Study Between Grape (Vitis vinifera) Juice Varieties on Liver Toxicity Induced by Sodium Fluoride in Adult Rats

Naglaa A. EL-Sheikh, Abeer A. Khed and Alaa H. Nofal
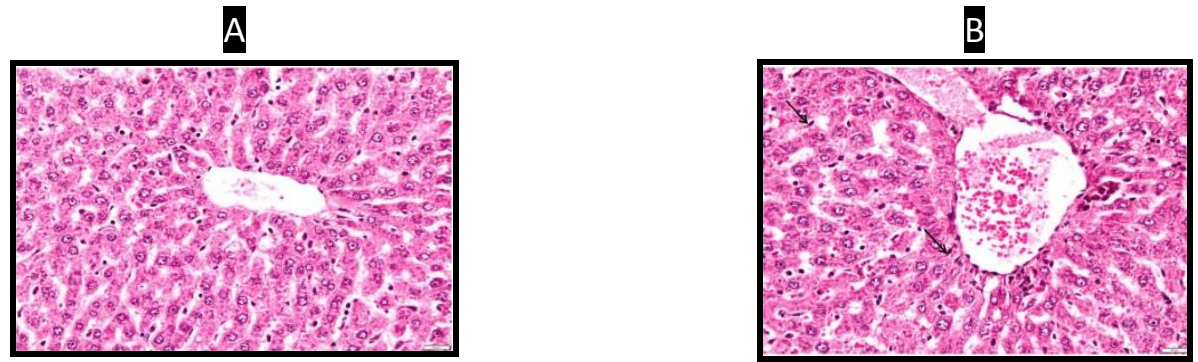

a
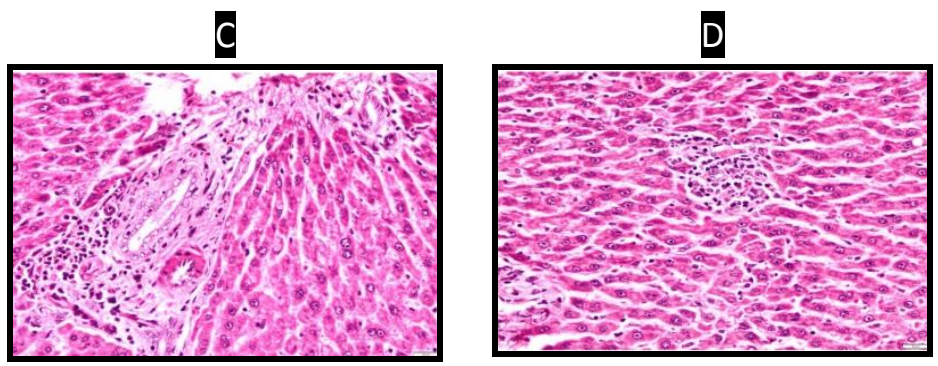

G

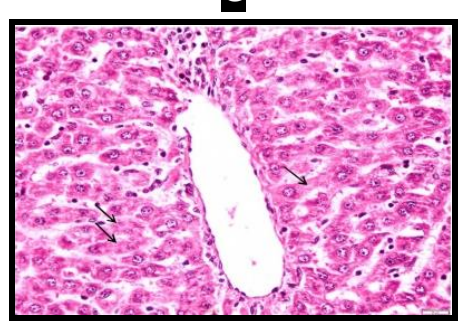

E

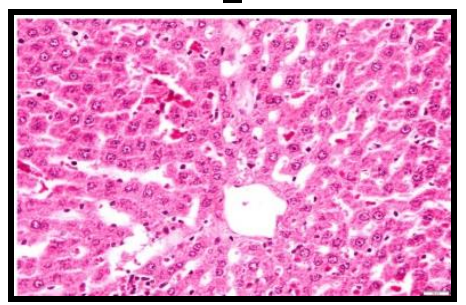

$\mathrm{H}$

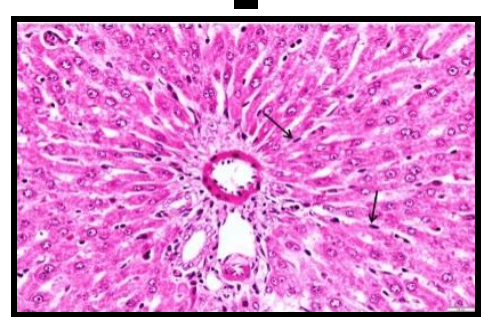

A: negative control, B: positive control (sodium fluoride group untreated), c: sodium fluoride group treated with $5 \mu \mathrm{l} / \mathrm{g} \mathrm{BW}$ of green (white) grape juice, D: sodium fluoride group treated with $5 \mu \mathrm{l} / \mathrm{g}$ BW of red grape juice, E: sodium fluoride group treated with $5 \mu \mathrm{l} / \mathrm{g} \mathrm{BW}$ of black grape juice, F: sodium fluoride group treated with $10 \mu \mathrm{l} / \mathrm{g}$ BW of green (white) grape juice, G: sodium fluoride group treated with $10 \mu \mathrm{l} / \mathrm{g}$ BW of red grape juice $\mathrm{H}$ : sodium fluoride group treated with $10 \mu \mathrm{l} / \mathrm{g}$ BW of black grape juice.

Photo (1): Effect of green (white), red and black grape juice on histological examination of liver tissues in hepatotoxicity rats. 


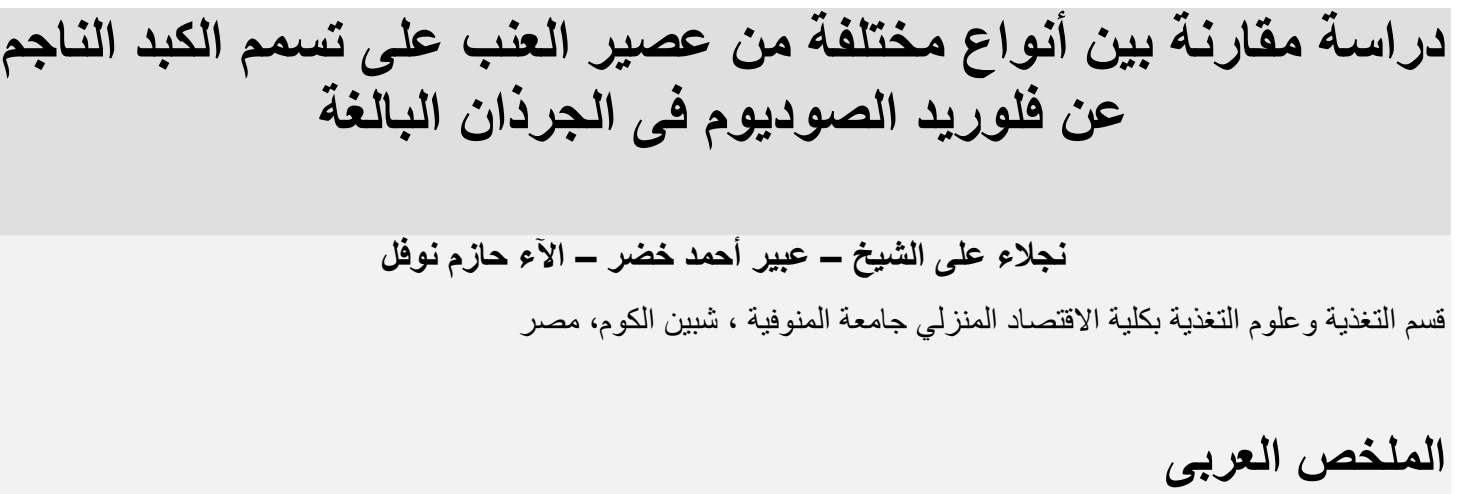

استهلاك الفواكه بلعب دورا هاما كعامل حماية للصحة ، ويتتبر عصبر العنب مشروب وقائى صحى نظرا

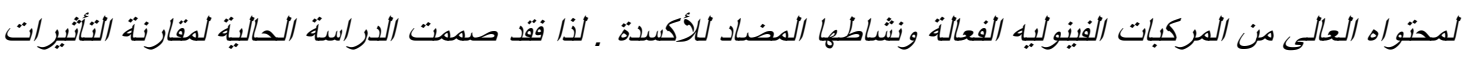

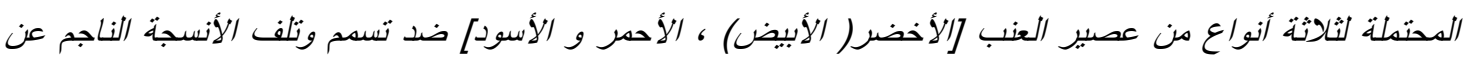

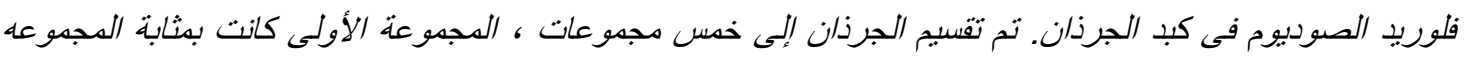

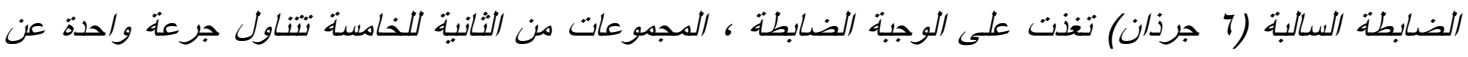

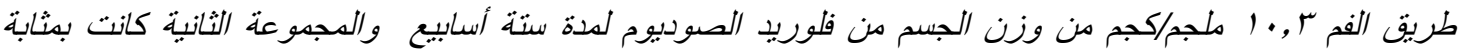

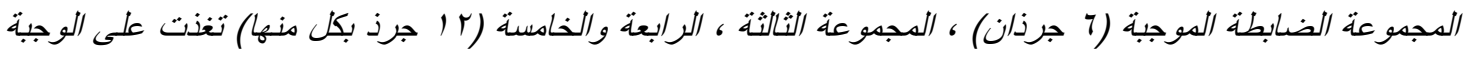

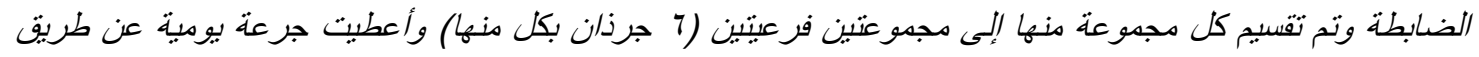

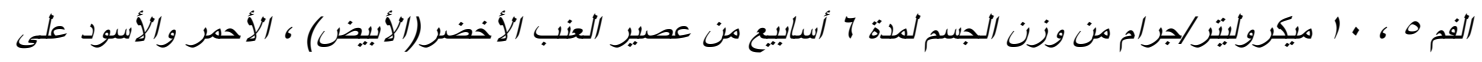

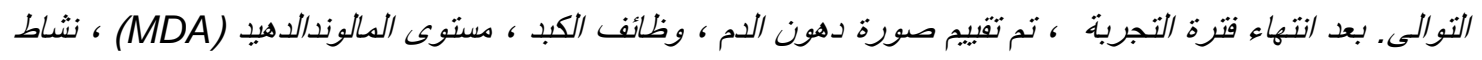

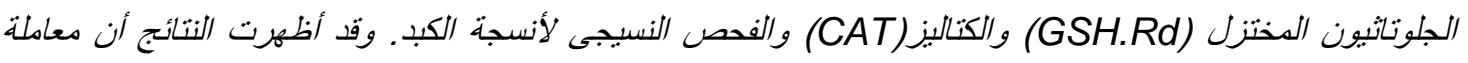

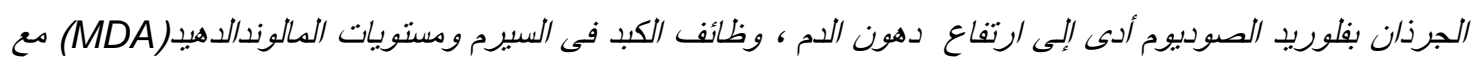

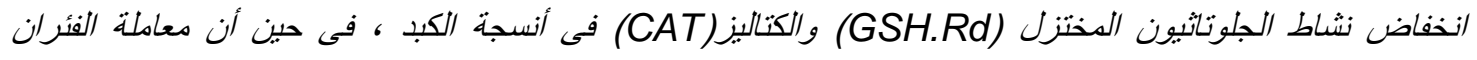
الدصابة بالتسمم بفلوريد الصوديوم بعصبر العنب الأحمر والأسود قد خفضت من مستويات دهون الدم ، انزيمات الكبد و

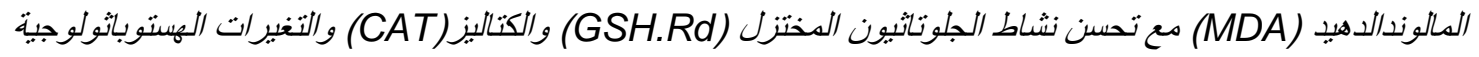

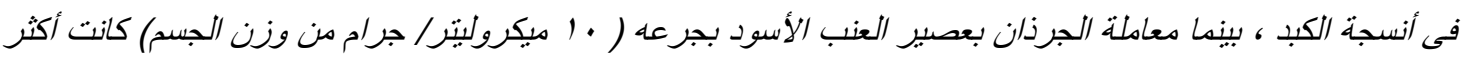

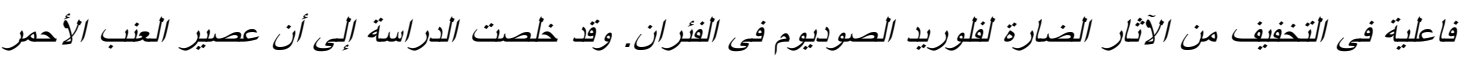

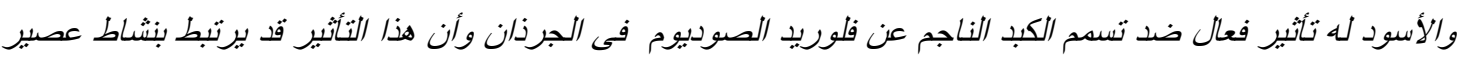
العنب المضاد للأكسدة. الكلمات الكشافة : تسمم الكبد - فلوريب الصوديوم - عصبير العنب الأحمر والأسود - وظائف الكبد. 